\title{
Non-covalent interactions of alkali metal cations with singly charged tryptic peptides
}

\author{
Marko Rožman and Simon J. Gaskell \\ The complexes formed by alkali metal cations $\left(\mathrm{Cat}^{+}=\mathrm{Li}^{+}, \mathrm{N} \mathrm{a}^{+}, \mathrm{K}^{+}, \mathrm{R} \mathrm{b}^{+}\right.$) and singly charged tryptic peptides were investigated by combining results from the low-energy \\ collision-induced dissociation (CID) and ion mobility experiments with molecular dynamics and density functional theory calculations. The structure and reactivity of $[\mathrm{M}+\mathrm{H}$ \\ + Cat $]^{2+}$ tryptic peptides is greatly influenced by charge repulsion as well as the ability of the peptide to solvate charge points. Charge separation between fragment ions \\ occurs upon dissociation, i.e. $\mathrm{b}$ ions tend to be alkali metal cationised while $\mathrm{y}$ ions are protonated, suggesting the location of the cation towards the peptide $\mathrm{N}$-terminus. The \\ low-energy dissociation channels were found to be strongly dependant on the cation size. Complexes containing smaller cations $\left(\mathrm{Li}^{+}\right.$or $\mathrm{Na}^{+}$) dissociate predominantly by \\ sequence-specific cleavages, whereas the main process for complexes containing larger cations $\left(\mathrm{Rb}^{+}\right)$is cation expulsion and formation of $[\mathrm{M}+\mathrm{H}]^{+}$. The obtained structural \\ data might suggest a relationship between the peptide primary structure and the nature of the cation coordination shell. Peptides with a significant number of side chain \\ carbonyl oxygens provide good charge solvation without the need for involving peptide bond carbonyl groups and thus forming a tight globular structure. However, due to \\ the lack of the conformational flexibility which would allow effective solvation of both charges (the cation and the proton) peptides with seven or less amino acids are unable \\ to form sufficiently abundant $[\mathrm{M}+\mathrm{H}+\mathrm{Cat}]^{2+}$ ion. Finally, the fact that $[\mathrm{M}+\mathrm{H}+\mathrm{Cat}]^{2+}$ peptides dissociate similarly as $[\mathrm{M}+\mathrm{H}]^{+}$(via sequence-specific cleavages, however, with the \\ additional formation of alkali metal cationised b ions) offers a way for generating the low-energy CID spectra of 'singly charged' tryptic peptides.
}

Keywords: structure-activity relationship; peptide structure; molecular modelling; collision-induced dissociation; alkali metals

\section{Introduction}

Over $30 \%$ of known proteins are metalloproteins. ${ }^{[1,2]}$ Protein-metal complexation as well as metal cation effects on structure is an important aspect in many fundamental biological processes. ${ }^{[3,4]}$ Although protein-metal complexes tend to favour divalent metals (e.g. catalytic centres) there is greater evidence for the important role of alkali metal ions, e.g. activation of enzymes, cellular metabolism, stabilisation of protein structure, etc. ${ }^{[4,5]}$ Another important aspect of protein/peptide-alkali metal interactions is in analytical applications, where fragmentation of these complexes within a mass spectrometer can provide useful information on the amino acid sequence of the peptide/protein. ${ }^{[6,7]}$

Mass spectrometry provides a gas-phase environment for studying the structure and properties of protein/peptide-alkali metal complexes. It can be argued that studying these complexes in the gas phase has little biological relevance. However, many structural features may be the same in the gas phase as in the solution phase, and there are some evidence that the gas-phase structure of peptide fragments may be utilised for the solution-phase relevant studies of the peptide folding. ${ }^{[8,9]}$ Furthermore, observed gas-phase properties can be correlated to the biologically observed properties as well as enabling the development of controllable and predictable fragmentation methods. $^{[6]}$

So far, the majority of the studies have focused on singly charged alkali cationised peptides (some of the examples can be found in Refs. [6-18]). Collision-induced dissociation (CID) of the singly charged alkali metal cationised peptides led to the sequential loss of amino acids from the C-terminus, i.e. C-terminal sequencing, ${ }^{[6]}$ with the exception of the peptides with acidic residues. ${ }^{[7]}$ Only a few studies have considered the behaviour of the doubly charged protonated and sodiated nontryptic peptides. ${ }^{[19,20]}$ Charge separation between $b$ and y ions was observed. The y ions were mainly observed as sodiated species, in agreement with the location of the sodium towards C-terminus of the peptide.

This study is focused on doubly charged, protonated and alkali cationised, tryptic peptides. The main reason for this is that the vast majority of mass spectrometry-based proteomic studies uses tryptic digests of protein mixtures. Tryptic digests, despite significant efforts in desalting, always contain some proportion of salt adducts. A strategy utilising those adducts and increasing the information yield of proteomic experiment would be very useful. Furthermore, in doubly charged protonated and alkali cationised tryptic peptides, the charged arginine or lysine residue on the $\mathrm{C}$-terminus may push the alkali cation towards the $\mathrm{N}$-terminus (because of Coulombic repulsion). This is expected to drive the 
charge separation between fragment ions, i.e. y ions are expected to be protonated, whereas $b$ ions are alkali metal cationised.

Here we address several issues of both 'pure' and 'applied' interest - in particular, how different alkali metal cations interact with the singly charged tryptic peptide backbone, how that interaction is reflected in their gas-phase fragmentation and how that can be utilised, e.g. for fast differentiation between $b$ and $y$ ions.

\section{Methods}

\section{Mass spectrometry and ion mobility}

All compounds used in the experiments were obtained from Sigma-Aldrich (Dorset, UK) without further purification. Peptide samples were made up to $10 \mu \mathrm{M}$ in 50:50:1 water/methanol/acetic acid and introduced into the ESI source by direct infusion at a flow rate of $100 \mu \mathrm{h} \mathrm{h}^{-1}$. The relative abundance of some $[\mathrm{M}+\mathrm{H}+\mathrm{Cat}]^{2+}$ species, especially in a case of rubidiated species, was increased by the addition of the alkali metal acetate to the sample solution.

CID experiments were performed on the 9.4 T Apex III Fouriertransform ion cyclotron resonance (FT-ICR) and the Esquire3000 quadrupole ion trap (IT) mass spectrometers (Bruker Daltonics, Coventry, UK). Both were equipped with Apollo electrospray ionisation sources. Argon (FT-ICR) or helium (IT) was employed for collisional cooling and as a collision gas. Mass selection and CID were carried out in the cell by using standard isolation and excitation procedures. On the IT, precursor ions were excited with a resonant RF. The excitation time was $40 \mathrm{~ms}$ and the $\mathrm{RF}$ amplitude was in the range of $0.44-0.75 \mathrm{~V}$. On the FT-ICR instrument, the sustained off-resonance irradiation (SORI) CID was used for $150-250 \mathrm{~ms}$, with activation $500-1000 \mathrm{~Hz}$ below resonance frequency.

Peptide-water interaction experiments were screened using gas-phase ion/molecule reactions within ICR cell. Experimental procedure similar to the gas-phase H/D exchange measurements (for more details about the gas-phase H/D exchange measurements, see Ref. [21]) followed by CID was used. Briefly, ions formed by ESI were transferred into ICR cell, mass selected and allowed to react $\left(10-20 \mathrm{~s}\right.$ ) with the background pressure of $\mathrm{H}_{2} \mathrm{O}$. $\mathrm{H}_{2} \mathrm{O}$ gas was introduced via a leak valve into the cell and the pressure used in the experiment was around $\sim 8 \times 10^{-8} \mathrm{~Pa}$ at the ambient temperature of $294 \mathrm{~K}$. After reaction delay, SORI CID was employed and mass spectra were taken.

Ion mobility experiments were performed on the Synapt High Definition mass spectrometer (Waters Corp., Manchester, UK), described in detail in Ref. [22]. Ions were formed by ESI (the source temperature was $353 \mathrm{~K}$ and the capillary voltage was set to $3.2 \mathrm{kV}$ ) and injected into the mobility region. The bath gas in the T-Wave ion mobility cell was nitrogen, and the pressure was 0.53 mbar. The T-Wave was operated at $300 \mathrm{~m} \mathrm{~s}^{-1}$ and linearly ramped in amplitude from 5 to $20 \mathrm{~V}$. Arrival time distributions were recorded by synchronising the orthogonal acceleration time-of-flight mass spectrometric acquisitions with the gated release of ions from the transfer T-Wave. Two hundred mass spectra were acquired for each packet of ions. Instrument control and data acquisition were carried out using MassLynx (v4.1) software (Waters Corp.).

\section{Molecular modelling and theoretical cross sections}

All theoretically studied tryptic peptide structures are assumed to be protonated on the arginine side chain (the most basic site), and the alkali metal cation was placed close to the centre of the peptide backbone. In the molecular dynamics (MD) calculations, $0.5 \mathrm{fs}$ integration step was used, all non-bonded interactions were calculated and peptide atomic charges were estimated via semiempirical AM1 method. A combination of quenched dynamics and simulated annealing was used to sample the potential energy surface. Simulations at the $800 \mathrm{~K}$ for 30 ps were followed by slow cooling to the $200 \mathrm{~K}$ over $10 \mathrm{ps}$, and geometry optimisation using a steepest descent approach. For some complexes with $\mathrm{K}^{+}$and especially with $\mathrm{Rb}^{+}$, we experienced expulsion of the cation during the simulations. Consequently, a part of dynamic simulations was carried out at $600 \mathrm{~K}$. Two hundred structures were generated with this procedure for an each peptide variant. The structures within $\sim 41 \mathrm{~kJ} \mathrm{~mol}^{-1}\left(10 \mathrm{kcal} \mathrm{mol}^{-1}\right)$ from the lowest energy conformer were selected as the candidate group. The theoretical cross section of an each structure was calculated using the SIGMA 'project approximation' algorithm with atomic radii determined from the ion-helium Lennard-Jones parameters. ${ }^{[23,24]}$ Average cross section was obtained from the candidate group. The conformational stability of the lowest energy structure (representative structure) was then tested with a $1 \mathrm{~ns}$ MD simulation at $300 \mathrm{~K}$.

In order to achieve a more accurate description of dissociation energies, representative structures were further optimised at the B3LYP/STO-3G* level of theory. Single point B3LYP calculations with the $6-311 \mathrm{G}(\mathrm{d}, \mathrm{p}$ ) basis set (for all atoms except the $\mathrm{Rb}$ cation) were used to obtain final energies. All MD simulations were performed using HyperChem (Waterloo, Ontario, Canada) with AMBER 99 force field, whereas quantum mechanics density functional theory calculations were performed using the GAUSSIAN 03. ${ }^{[25]}$

\section{Results}

Figure 1 represents an example of the effect of the sodium cation on the dissociation process. By considering the sequence of [Glu ${ }^{1}$ ]-fibrinopeptide B (GluFib, EGVNDNEEGFFSAR), $[\mathrm{M}+\mathrm{H}]^{+}$ is expected to produce fragments associated with the selective cleavage of the amide bond, C-terminal to the acid residue upon collisional excitation; the so-called 'aspartic acid effect' (i.e. $\mathrm{y}_{6}$, $\mathrm{y}_{7}, \mathrm{y}_{9}$ or $\left.\mathrm{y}_{13}\right)$. This is indeed observed in experiments where fragmentation result from the initial excitation of the whole desorbed ion population during the MALDI process. ${ }^{[26]}$ However, if the molecular ion is selected and subjected to the low-energy CID, the main fragmentation path is the loss of water (Fig. 1(a)). Further excitation of $[\mathrm{M}+\mathrm{H}-18]^{+}$produces fragments $\mathrm{y}_{6}$ and $\mathrm{y}_{9}$ which can be attributed to the aspartic acid effect. Observed fragment ions suggest that the loss of water is from the $\mathrm{Glu}^{1}$ residue. Similar behaviour was observed for singly charged (no basic residues, proton on N-terminal nitrogen) peptides containing Glu at the N-terminus ${ }^{[27,28]}$ (Scheme $1(\mathrm{a})$ ). In our case the ionising proton is most likely to be located on the arginine side chain suggesting that the neutral N-terminal Glu can exhibit expulsion of water, (Scheme 1(b)).

The addition of the sodium cation to $[\mathrm{M}+\mathrm{H}]^{+}$and subsequent collisional excitation of $[\mathrm{M}+\mathrm{H}+\mathrm{Na}]^{2+}$ produces y ions connected with the aspartic acid effect (Fig. 1(b)). However, the corresponding $\mathrm{b}$ ions also appear in the spectrum as $\left[\mathrm{b}_{n}-\mathrm{H}+\mathrm{Na}\right]^{+}$suggesting charge separation due to the Coulombic repulsion during lowenergy CID. Formation of $\left[\mathrm{y}_{13}+\mathrm{Na}\right]^{2+}$ appears to be in contrast with latter, however, that is not the case as it will be explained in one of the following sections. 
(a)<smiles>CC(C)CCCCCNC(=O)C([NH3+])CCC(=O)O</smiles>

(b)

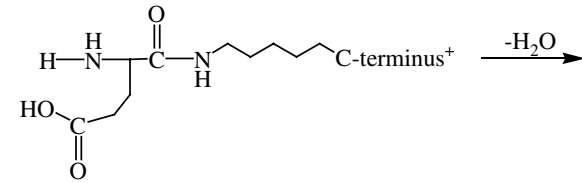

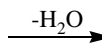<smiles>CC(C)CCCCCNC(=O)C1CCC(=O)N1</smiles><smiles>[CH2+]C(Cl)CCCCCNC(=O)C1CCC(=O)N1</smiles>

Scheme 1. Loss of water from N-terminal Glu residue.
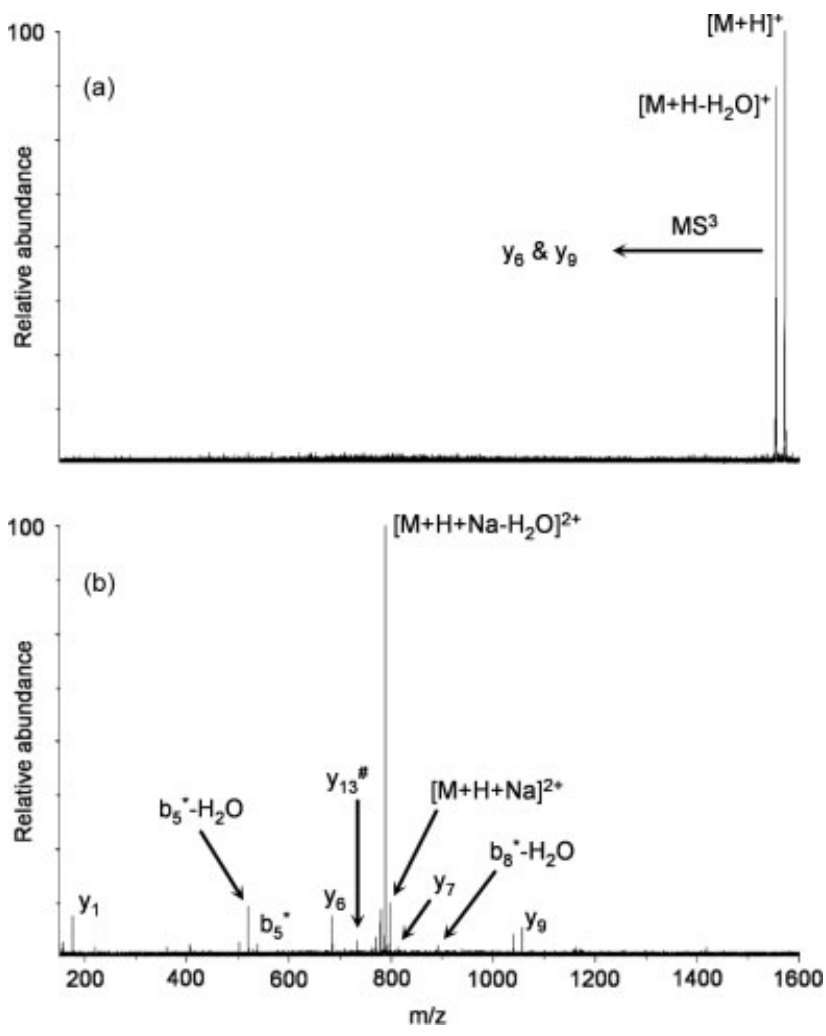

Figure 1. Mass spectra illustrating low-energy CID pathways of (a) singly protonated GluFib and (b) doubly charged protonated/sodiated GluFib $\left(\mathrm{b}_{n}{ }^{*}=\left[\mathrm{b}_{n}-\mathrm{H}+\mathrm{Na}\right]^{+}, \mathrm{y}_{n}{ }^{\#}=\left[\mathrm{y}_{n}+\mathrm{Na}\right]^{2+}\right)$.

To provide greater insight into the binding of the metal ion, ion mobility experiments and MD simulations were performed. Figure 2 illustrates assigned structures of $[\mathrm{M}+\mathrm{H}]^{+}$and $[\mathrm{M}+\mathrm{H}+$ $\mathrm{Na}]^{2+}$ of GluFib. Ion mobility results for protonated GluFib indicate fairly wide distribution of populations (Fig. 2(a)) with maxima corresponding to the drift time of 8.87 and $9.46 \mathrm{~ms}$. The structure with the larger cross section (corresponds to larger drift time) is depicted in Fig. 2(b). MD simulations suggest that the central part of the backbone folds into a stable loop solvating the Arg side chain making the $\mathrm{C}$-terminus fairly rigid. The $\mathrm{N}$-terminus, on the other hand, remains relatively flexible which might explain relative wide cross-section distribution. It is important to note that $\mathrm{Glu}^{1}$ side chain is not sterically hindered or involved in any non-covalent interactions and can be easily activated. The remaining part of the population is represented by a more compact globular structure stabilised with multiple hydrogen bonds and capped with Arg side chain (Fig. 2(c)). Here, the Glu ${ }^{1}$ side chain is involved in hydrogen bonding which most likely hinders activation.

The arrival time distribution of $[\mathrm{M}+\mathrm{H}+\mathrm{Na}]^{2+}$ yielded a single population with the drift time of $4.83 \mathrm{~ms}$ (spectrum not shown). MD simulations suggest that the sodiated/protonated GluFib is influenced by Columbic repulsion between the protonated guanidinium group and the sodium cation causing $\mathrm{Na}^{+}$placement towards the N-terminus (Fig. 2(d)). The presence of the sodium cation causes rigidification of the $\mathrm{N}$-terminus due to multiple electrostatic interactions of carbonyl oxygen atoms with the sodium cation. A number of side chain carbonyl oxygens (Asp, Glu, Asn residues) provide a fairly good charge solvation shell (five ligands of which four are from side chains) without the need for involving much of the peptide bond carbonyl groups.

Although the GluFib example illustrates how attachment of the sodium cation alters the gas-phase structure and the low-energy CID process, the effects of different alkali metal cations and peptide primary structure implications need to be determined.

\section{Effect of different alkali metal cations}

Figure 3 shows the CID fragment ion mass spectra of the alkali metal cationised osteocalcin fragments 7-19 (GAPVPYPDPLEPR). The lithiated and sodiated precursor ions dissociate exclusively by producing $b$ and $y$ type fragment ions associated with the aspartic acid effect. Potassiated osteocalcin dissociates predominantly by producing $\mathrm{b}$ and $\mathrm{y}$ ions, however, with additional metal ion expulsion (observed on the IT data, see Supporting Information). For rubidiated peptides, the loss of the alkali metal cation becomes even more pronounced. Similar, in a way consistent, behaviour was observed for cationised des-Arg-bradykinins, where $\mathrm{Cs}^{+}$adducts (in contrast to $\mathrm{Na}^{+}$and $\mathrm{K}^{+}$) produced very simple post-source decay spectra dominated by metal ion signal. ${ }^{[15]}$ These results suggest that the dissociation process is strongly dependant on cation size, with small alkali metal ions $\mathrm{Li}^{+}$and $\mathrm{Na}^{+}$complexing more strongly than the larger $\mathrm{K}^{+}$and $\mathrm{Rb}^{+}$in agreement with previous observations on similar systems. ${ }^{[17,29]}$

According to the ion mobility measurements and the theoretical modelling data, conformation of the osteocalcin does not change significantly with cation size (Table 1). Osteocalcin forms a tight globular structure with the predominant interaction between the alkali metal cation and peptide bond carbonyl groups. Charge solvation within the tight loop is a preferred binding site for all alkali metal cations (Fig. 3). Due to the larger ionic radius, $\mathrm{K}^{+}$ and $\mathrm{Rb}^{+}$have five ligands involved in the coordination shell, whereas $\mathrm{Li}^{+}$and $\mathrm{Na}^{+}$have four. $\mathrm{Li}^{+}$with the smallest ionic binds most strongly to the osteocalcin, whereas larger cations bind less strongly (Table 1). Interestingly, estimated magnitude of $\mathrm{K}^{+}$and $\mathrm{Rb}^{+}$bond dissociation energies $\left(100-150 \mathrm{~kJ} \mathrm{~mol}^{-1}\right)$ lies around 


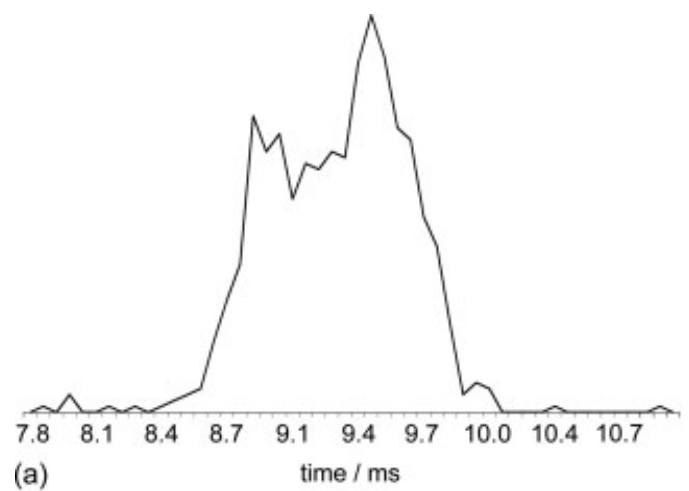

(a)

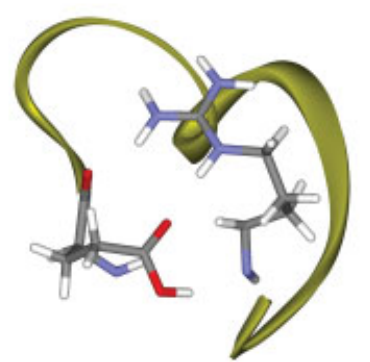

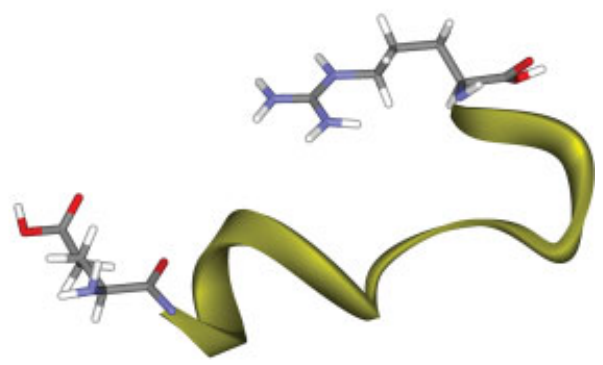

(b)

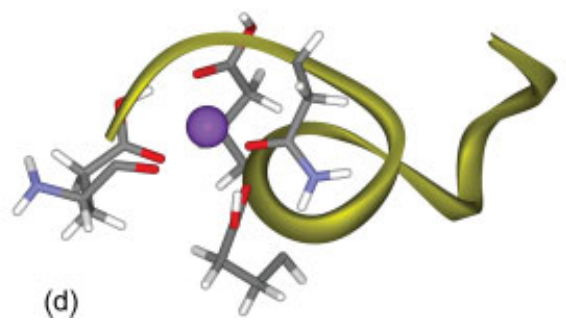

Figure 2. Ion arrival time distribution for $[\mathrm{M}+\mathrm{H}]^{+}$GluFib; maxima correspond to the drift time of 8.87 and $9.46 \mathrm{~ms}$ (a). Representative GluFib low-energy conformations; (b) singly charged $[\mathrm{M}+\mathrm{H}]^{+}$with calculated cross section of $290 \pm 4 \AA^{2}$. (c) singly charged [M $\left.+\mathrm{H}\right]^{+}$with calculated cross section of $279 \pm 2 \AA^{2}$. (d) Doubly charged protonated/sodiated $[\mathrm{M}+\mathrm{H}+\mathrm{Na}]^{2+}$ with calculated cross section of $301 \pm 7 \AA^{2}$.

threshold for Asp effect; which is $100-130 \mathrm{~kJ} \mathrm{~mol}^{-1}$ for unhindered Asp side chain. ${ }^{[30]}$ Thus, this comparison could explain why for rubidated peptides metal expulsion becomes a dominant process.

Additionally, we wanted to check is there a change in the system $\left([\mathrm{M}+\mathrm{H}+\mathrm{Cat}]^{2+}\right)$ behaviour as a consequence of the interaction with water medium. Interaction with water could induce either further stabilisation or a change in the peptide conformation (e.g. for some amino acids and peptides it is shown that one molecule of water may alter the relative stability of the conformers ${ }^{[31-33]}$ ) and which may influence the reaction path of the molecule, e.g. the CID process. Hydration effects were screened using gasphase ion/molecule reactions within the ICR cell, i.e. selected peptide ions were allowed to react with background pressure of $\mathrm{H}_{2} \mathrm{O}$ and subsequently subjected to SORI CID. The SORI CID spectra produced were identical to those obtained without interaction with water, suggesting that the initial conformation is not significantly changed at least not in a way that will affect the dissociation process.

\section{Influence of peptide primary structure}

The results from a series of experiments (similar to those illustrated) performed on tryptic-like peptides are summarised in Table 2. The presented data set allows several conclusions and implications to be made. In general, charge separation between fragment ions (b ions are alkali metal cationised, whereas y ions are protonated) occurs upon fragmentation. Peptides with seven or fewer amino acids are unable to form sufficiently abundant $[\mathrm{M}+\mathrm{H}+\mathrm{Cat}]^{2+}$ ions. For shorter peptide chain lengths, the lack of conformational flexibility which allows effective solvation of both charge points by carbonyl oxygen's make charge-charge repulsion main reason why $[\mathrm{M}+\mathrm{H}+\mathrm{Cat}]^{2+}$ ions are not formed. This observation is consistent with recent theoretical calculations on a series of oligoglycine ions which found that the formation of
Table 1. Drift times (in ms) and calculated cross sections (in $\AA^{2}$ ) along with dissociation energies (in $\mathrm{kJ} \mathrm{mol}^{-1}$ ) of cationised osteocalcin

\begin{tabular}{|c|c|c|c|c|}
\hline \multirow[b]{2}{*}{ Species } & \multirow[b]{2}{*}{ Drift time } & \multirow[b]{2}{*}{ Cross section $^{a}$} & \multicolumn{2}{|c|}{ Energy } \\
\hline & & & $\Delta^{\mathrm{a}}$ & $\Delta^{\mathrm{b}}$ \\
\hline$[\mathrm{M}+\mathrm{H}]^{+}$ & 9.13 & $281 \pm 6$ & - & - \\
\hline$[\mathrm{M}+\mathrm{H}+\mathrm{Li}]^{2+}$ & 4.57 & $274 \pm 4$ & -320.1 & -377.4 \\
\hline$[\mathrm{M}+\mathrm{H}+\mathrm{Na}]^{2+}$ & 4.63 & $273 \pm 5$ & -189.2 & -148.4 \\
\hline$[\mathrm{M}+\mathrm{H}+\mathrm{K}]^{2+}$ & 4.7 & $274 \pm 4$ & -127.9 & -153.9 \\
\hline$[\mathrm{M}+\mathrm{H}+\mathrm{Rb}]^{2+}$ & 4.7 & $274 \pm 6$ & -100.7 & - \\
\hline
\end{tabular}

the $[\mathrm{M}+\mathrm{H}+\mathrm{Na}]^{2+}$ complex is endothermic for peptides with five or less glycines. ${ }^{[17]}$

Structural data obtained for GluFib and osteocalcin suggest a possible relationship between the primary peptide structure and the nature of the sodium coordination shell formed. Peptides with a significant number of side chain carbonyl oxygens (e.g. GluFib) can provide a good charge solvation shell without the need for involving much of the peptide bond carbonyl groups and thus necessitating the formation of a tight globular structure with the predominant interaction between alkali metal cation and peptide bond carbonyl groups (e.g. osteocalcin). However, a significant number of side chain carbonyl oxygen cannot exclude formation of tight structure due to effective salvation/neutralisation of the cation charge and thus allowing closer positioning of protonated C-terminus.

It is interesting to note that $\left[\mathrm{b}_{3}-\mathrm{H}+\mathrm{Na}\right]^{+}$is the smallest b ion observed (Table 2). Despite, in some cases (PPGFSPFR and ADSGEGDFLAEGGGVR), a prominent cleavage at the C-terminal side of the second amino acid residue, the corresponding $\left[\mathrm{b}_{2}-\mathrm{H}\right.$ 


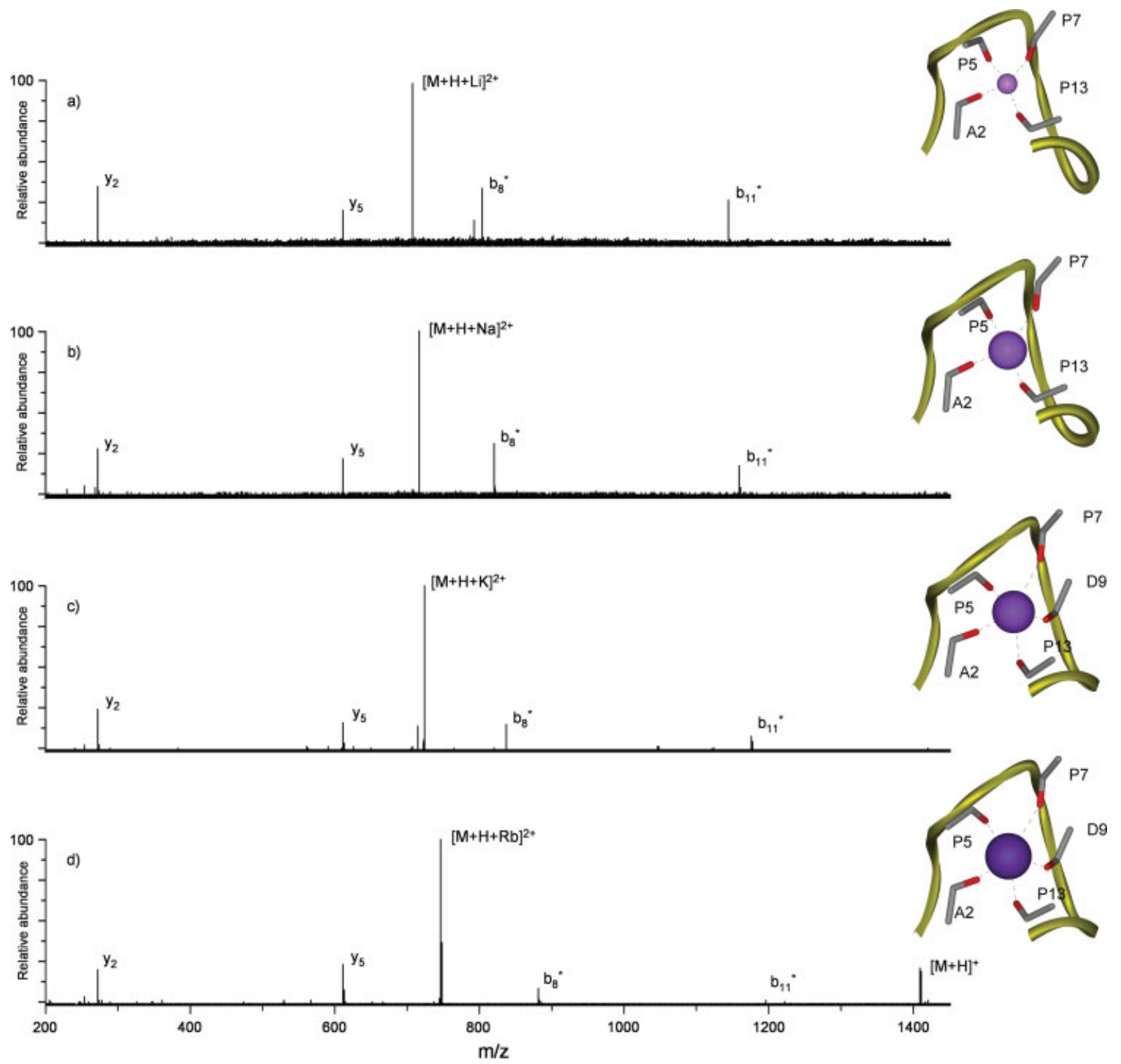

Figure 3. SORI CID spectra together with low-energy conformations of doubly charged protonated/alkali metal cationised osteocalcin: $(\mathrm{a})[\mathrm{M}+\mathrm{H}+\mathrm{Li}]^{2+}$, (b) $[\mathrm{M}+\mathrm{H}+\mathrm{Na}]^{2+}$, (c) $[\mathrm{M}+\mathrm{H}+\mathrm{K}]^{2+}$ and (d) $[\mathrm{M}+\mathrm{H}+\mathrm{Rb}]^{2+}$.

$+\mathrm{Na}]^{+}$fragment ion was not observed. Instead, the sodium cation was attached to the $y$ ion, forming $\left[\mathrm{y}_{n-2}+\mathrm{Na}\right]^{2+}$. This observation suggests that despite Coulombic repulsion, y ion provides better charge solvation shell for the sodium cation and thus possesses higher sodium affinity. This is consistent with the rigidity of cyclic anhydride structure proposed for b-type ions formed by the aspartic acid effect ${ }^{[30]}$ which will be especially pronounced for the smallest $b$ ion.

\section{Analytical implications}

In general, during tandem $\mathrm{MS}[\mathrm{M}+\mathrm{H}+\mathrm{Cat}]^{2+}$ peptides exhibit behaviour like $[\mathrm{M}+\mathrm{H}]^{+}$species, i.e. sequence-specific cleavages, however, with the additional formation of the alkali metal cationised $b$ ions (Table 1). The dissociation of $[\mathrm{M}+\mathrm{H}+\mathrm{Cat}]^{2+}$ ions offers a way to generate CID spectra of 'singly charged' tryptic peptides. This is especially useful in ESI which generally tends to form multiply charged ions. Furthermore, by combing information from CID spectra of singly (here $[\mathrm{M}+\mathrm{H}+\mathrm{Cat}]^{2+}$ ) and doubly charged precursor ions in the same experiment, the benefits of the charge remote and the charge-directed cleavage can be exploited and possibly improve the identification process without increasing the workload. Slightly different coupling, spectra of peptides cationised with different alkali metal cations (as in Fig. 3), will allow us to distinguish between classes of ions ( $b$ and $y$ ) without any prior knowledge of the peptide sequence. When overlapping those spectra, $y$ ions have the same mass whereas $b$ ions have the mass shift in accordance with mass difference between corresponding cationising metals. The fact that in some cases large $y$ ions tend to retain a cation can reduce the utility of the proposed experiment. However, only to a limited extend, cause y ions with retained cation will be doubly charged, thus shifting in half mass difference between corresponding cationising metals.

However, with ESI as a method of choice for generating $[\mathrm{M}+\mathrm{H}+\mathrm{Cat}]^{2+}$ ions there could be some difficulties with obtaining high abundance of the specific metal cationised ion of interest. The presence of small amounts of metal salts in the electrospray 
Table 2. Fragment ions observed in low-energy CID spectra of $[\mathrm{M}+\mathrm{H}]+$ and $[\mathrm{M}+\mathrm{H}+\mathrm{Na}] 2+$

\begin{tabular}{|c|c|c|c|}
\hline \multirow[b]{2}{*}{ Sequence } & \multirow[b]{2}{*}{ Species } & \multicolumn{2}{|c|}{ Fragment ions } \\
\hline & & b ions & $y$ ions \\
\hline \multicolumn{4}{|l|}{ AFLDASK } \\
\hline AFLNASR & \multicolumn{3}{|c|}{ Do not form $[\mathrm{M}+\mathrm{H}+\mathrm{Na}]^{2+}$} \\
\hline \multicolumn{4}{|l|}{ SIGSLAK } \\
\hline \multirow[t]{2}{*}{ PPGFSPFR } & {$[\mathrm{M}+\mathrm{H}]^{+}$} & $b_{7}$ & $\mathrm{y}_{1}, \mathrm{y}_{6}$ \\
\hline & {$[\mathrm{M}+\mathrm{H}+\mathrm{Na}]^{2+}$} & $b_{7}^{a}$ & $y_{1}, y_{6}, y_{6},{ }^{b} y_{7}^{b}$ \\
\hline \multirow[t]{2}{*}{ VQGEESNDK } & {$[\mathrm{M}+\mathrm{H}]^{+}$} & $b_{2}, b_{4}, b_{5}, b_{7}, b_{8}$ & $y_{1}, y_{2}, y_{3}, y_{4}, y_{5}, y_{7}$ \\
\hline & {$[\mathrm{M}+\mathrm{H}+\mathrm{Na}]^{2+}$} & $b_{2}, b_{3},{ }^{a} b_{4},{ }^{a} b_{5},{ }^{a} b_{8}{ }^{a}$ & $\mathrm{y}_{1}, \mathrm{y}_{4}$ \\
\hline \multirow[t]{2}{*}{ HSDAVFTDNYTR } & {$[\mathrm{M}+\mathrm{H}]^{+}$} & & $\mathrm{y}_{4}, \mathrm{y}_{9}$ \\
\hline & {$[\mathrm{M}+\mathrm{H}+\mathrm{Na}]^{2+}$} & $b_{3},{ }^{a} b_{8}{ }^{a}$ & $y_{4}, y_{9}, y_{9}^{b}$ \\
\hline \multirow[t]{2}{*}{ GAPVPYPDPLEPR } & {$[\mathrm{M}+\mathrm{H}]^{+}$} & & $y_{2}, y_{5}$ \\
\hline & {$[\mathrm{M}+\mathrm{H}+\mathrm{Na}]^{2+}$} & $\mathrm{b}_{8}, \mathrm{~b}_{11}^{\mathrm{a}}$ & $y_{2}, y_{5}$ \\
\hline \multirow[t]{2}{*}{ EGVNDNEEGFFSAR } & {$[\mathrm{M}+\mathrm{H}]^{+}$} & $b_{14}$ & $\left(y_{6}, y_{9}\right)$ \\
\hline & {$[\mathrm{M}+\mathrm{H}+\mathrm{Na}]^{2+}$} & $b_{5},{ }^{a} b_{8}{ }^{a}$ & $y_{1}, y_{6}, y_{7}, y_{9}, y_{13}^{b}$ \\
\hline \multirow[t]{2}{*}{ ADSGEGDFLAEGGGVR } & {$[\mathrm{M}+\mathrm{H}]^{+}$} & & $y_{1}, y_{5}, y_{9}, y_{11}, y_{14}$ \\
\hline & {$[\mathrm{M}+\mathrm{H}+\mathrm{Na}]^{2+}$} & $b_{5}, b_{7}, b_{11}{ }^{a}$ & $y_{1}, y_{5}, y_{9}, y_{11}, y_{14} b$ \\
\hline
\end{tabular}

solution may significantly reduce a peptide ion abundance due to both the suppression of ionisation and the formation of multiple species having metal adducts. However, new methods for the controlled generation of a metal cationised peptide ions are emerging such as cation switching ion/ion reactions. ${ }^{[34]}$

\section{Conclusions}

The work presented here reveals some insights into the noncovalent interactions of tryptic peptides and alkali metal cations in the gas phase. Important findings can be summarised as follows:

The structure and reactivity of $[\mathrm{M}+\mathrm{H}+\mathrm{Cat}]^{2+}$ tryptic peptides are greatly influenced by charge repulsion as well as the ability of the peptide to solvate cations. Charge separation between fragment ions occurs upon dissociation, i.e. $b$ ions tend to be alkali metal cationised whereas y ions are protonated, suggesting the location of the cation towards the peptide $\mathrm{N}$-terminus.

Low-energy dissociation process is strongly dependant on the cation size. Smaller cation $\left(\mathrm{Li}^{+}\right.$or $\left.\mathrm{Na}^{+}\right)$complexes dissociate by sequence-specific cleavages whereas complexes with larger cations $\left(\mathrm{Rb}^{+}\right)$dissociate by cation expulsion which is consistent with calculated bond dissociation energies.

Peptides with a significant number of side chain carbonyl oxygen's can provide a good charge solvation without need for involving much of the peptide bond carbonyl groups and thus forming of a tight globular structure.

$[\mathrm{M}+\mathrm{H}+\mathrm{Cat}]^{2+}$ peptides dissociate in similar manner as $[\mathrm{M}$ $+\mathrm{H}]^{+}$, i.e. following charge-remote dissociation pathways, offering a way to generate a low-energy CID spectrum of the 'singly charged' tryptic peptides.

\section{Acknowledgments}

We acknowledge Dr Isabel Riba Garcia (MBCMS, University of Manchester, UK) for ion mobility measurements. Helpful discussions with the members of the Michael Barber Centre for Mass Spectrometry are gratefully acknowledged. Croatian Academy of Sciences and Arts Foundation, The Ministry of Science, Education and Sports of Republic of Croatia (Grant Number: 098-0982915-2945) and The Engineering and Physical Sciences Research Council (Grant Number: EP/D013615/1) supported this work.

\section{Supporting information}

Supporting information may be found in the online version of this article.

\section{References}

[1] J. A. Ibers, R. H. Holm. Modeling coordination sites in metallobiomolecules. Science 1980, 209, 223.

[2] J. M. Castagnetto, S. W. Hennessy, V. A. Roberts, E. D. Getzoff, J. A. Tainer, M.E. Pique. MDB: the metalloprotein database and browser at The Scripps Research Institute. Nucl. Acids Res. 2002, 30 , 379.

[3] L. Stryer. Biochemistry, W. H. Freeman: New York, 1988.

[4] M. J.Page, E. Di Cera. Role of $\mathrm{Na}^{+}$and $\mathrm{K}^{+}$in enzyme function. Physiol. Rev. 2006, 86, 1049.

[5] M. J.Page, R. T. A. Macgillivray, E. Di Cera. Determinants of specificity in coagulation proteases. J. Thromb. Haemost. 2005, $3,2401$.

[6] T. Lin, G. L. Glish. C-terminal peptide sequencing via multistage mass spectrometry. Anal. Chem. 1998, 70, 5162.

[7] S. W. Lee, H. S. Kim, J. L. Beauchamp. Salt bridge chemistry applied to gas-phase peptide sequencing: selective fragmentation of sodiated gas-phase peptide ions adjacent to aspartic acid residues. J. Am. Chem. Soc. 1998, 120, 3188.

[8] M. Kohtani, B. S. Kinnear, M. F. Jarrold. Metal-ion enhanced helicity in the gas phase. J. Am. Chem. Soc. 2000, 122, 12377.

[9] B.T. Ruotolo, D. H. Russell. Gas-phase conformations of proteolytically derived protein fragments: influence of solvent on peptide conformation. J. Phys. Chem. B 2004, 108, 153211.

[10] L. M. Mallis, D. H. Russell. Fast atom bombardment-tandem mass spectrometry studies of organo-alkali metal ions of small peptides. Anal. Chem. 1986, 58, 1076. 
[11] R. P. Grese, R. L. Cerny, M. L. Gross. Metal ion-peptide interactions in the gas phase: a tandem mass spectrometry study of alkali metal cationized peptides. J. Am. Chem. Soc. 1989, 111, 2835.

[12] L. M. Teesch, R. C. Orlando, J. Adams. Location of the alkali metal ion in gas-phase peptide complexes. J. Am. Chem. Soc. 1991, 113, 3668.

[13] T. Wyttenbach, J. E. Bushnell, M. T. Bowers. Salt bridge structures in the absence of solvent? The case for the oligoglycines. J. Am. Chem. Soc. 1998, 120, 5098

[14] T. Solouki, R. C. Fort Jr., A. Alomary, A. Fattahi. Gas phase hydrogen deuterium exchange reactions of a model peptide: FT-ICR and computational analyses of metal induced conformational mutations. J. Am. Soc. Mass Spectrom. 2001, 12, 1272.

[15] B. A. Cereda, L. Cornett, C. Wesdemiotis. Probing the interaction of alkali and transition metal ions with bradykinin and its desarginine derivatives via matrix-assisted laser desorption/ionization and postsource decay mass spectrometry. Int. J. Mass Spectrom. 1999, 193, 205.

[16] W. Y. Feng, S. Gronert, K. A. Fletcher, A. Warres, C. B. Lebrilla. The mechanism of C-terminal fragmentations in alkali metal ion complexes of peptides. Int. J. Mass Spectrom. 2003, 222, 117.

[17] H. Ai, Y.Bu, P. Li, S. Yan. The peptide-chain size dependence of positive dissociation energy effect in metallized and protonated polydentate oligoglycine peptides. J. Chem. Phys. 2005, 123, 134307.

[18] P. Wang, C. Wesdemiotis, C. Kapota, G. Ohanessian. The sodium ion affinities of simple di-, tri-, and tetrapeptides. J. Am. Soc. Mass Spectrom. 2007, 18, 541.

[19] M. Kanai, A. lida, Y. Nagaoka, S. Wada, T. Fujita. Fungal metabolites. $\mathrm{XXI}$. Characteristics of low energy collision induced dissociation of $[\mathrm{M}+2 \mathrm{H}]^{2+},[\mathrm{M}+\mathrm{H}+\mathrm{Na}]^{2+}$ and $[\mathrm{M}+2 \mathrm{Na}]^{2+}$ of peptaibols using electrospray ionization mass spectrometry. J. Mass Spectrom. 1996, $31,177$.

[20] D. Bensadek, F. Monigatti, J.A. J.Steen, H. Steen. Why b, y's? Sodiation-induced tryptic peptide-like fragmentation of non-tryptic peptides. Int. J. Mass Spectrom. 2007, 268, 181.

[21] M. K. Green, C. B. Lebrilla. Ion-molecule reactions as probes of gasphase structures of peptides and proteins. Mass Spectrom. Rev. 1997, 16, 53.

[22] S. D. Pringle, K. Giles, J. L. Wildgoose, J.P. Williams, S. E. Slade, K. Thalassinos, R. H. Bateman, M. T. Bowers, J.H.Scrivens. An investigation of the mobility separation of some peptide and protein ions using a new hybrid quadrupole/travelling wave IMS/oa-ToF instrument. Int. J. Mass Spectrom. 2006, 261, 1.

[23] G. von Helden, M.-T. Hsu, N. G. Gotts, M. T. Bowers. Carbon cluster cations with up to 84 atoms: structures, formation mechanism, and reactivity. J. Phys. Chem. 1993, 97, 8182.
[24] T. Wyttenbach, G. von Helden. J. J. Batka Jr., D. Carlat, M. T. Bowers. Effect of the long-range potential on ion mobility measurements. J. Am. Soc. Mass Spectrom. 1997, 8, 275.

[25] M. J. Frisch, G. W. Trucks, H. B. Schlegel, G. E. Scuseria, M. A. Robb, J.R. Cheeseman, J.A. Montgomery Jr., T. Vreven, K. N. Kudin, J.C. Burant, J.M. Millam, S. S. lyengar, J. Tomasi, V. Barone, B. Mennucci, M. Cossi, G.Scalmani, N. Rega, G. A.Petersson, H. Nakatsuji, M. Hada, M. Ehara, K. Toyota, R. Fukuda, J. Hasegawa, M. Ishida, T. Nakajima, Y. Honda, O. Kitao, H. Nakai, M. Klene, X. Li, J. E. Knox, H. P. Hratchian, J. B. Cross, C. Adamo, J. Jaramillo, R. Gomperts, R. E. Stratmann, O. Yazyev, A. J. Austin, R. Cammi, C. Pomelli, J. W. Ochterski, P. Y. Ayala, K. Morokuma, G. A. Voth, P.Salvador, J.J.Dannenberg, V. G. Zakrzewski, S. Dapprich, A. D. Daniels, M. C. Strain, O. Farkas, D. K. Malick, A. D. Rabuck, K. Raghavachari, J. B. Foresman, J. V. Ortiz, Q. Cui, A. G. Baboul, S. Clifford, J.Cioslowski, B. B.Stefanov, G. Liu, A. Liashenko, P. Piskorz, I. Komaromi, R. L. Martin, D. J. Fox, T. Keith, M. A. AlLaham, C. Y. Peng, A. Nanayakkara, M. Challacombe, P. M. W. Gill, B. Johnson, W. Chen, M. W. Wong, C. Gonzalez, J. A. Pople. Gaussian 03, Revision B.05, Gaussian, Inc., Pittsburgh, PA, 2003.

[26] J. Qin, B.T. Chait. Preferential fragmentation of protonated gasphase peptide ions adjacent to acidic amino acid residues. J. Am. Chem. Soc. 1995, 117, 5411.

[27] A. G. Harrison. Fragmentation reactions of protonated peptides containing glutamine or glutamic acid. J. Mass Spectrom. 2003, 38, 174.

[28] B. Paizs, S. Suhai. Fragmentation pathways of protonated peptides. Mass Spectrom. Rev. 2005, 24, 508.

[29] S. Hoyau, G. Ohanessian. Interaction of alkali metal cations $\left(\mathrm{Li}^{+}-\mathrm{Cs}^{+}\right)$with glycine in the gas phase: a theoretical study. Chem. Eur. J. 1998, 4, 1561.

[30] M. Rožman. Aspartic acid side chain effect-experimental and theoretical insight. J. Am. Soc. Mass Spectrom. 2007, 18, 121.

[31] H. A. Cox, R. R. Julian, S. W. Lee, J. L. Beauchamp. Gas-phase H/D exchange of sodiated glycine oligomers with $\mathrm{ND}_{3}$ : exchange kinetics do not reflect parent ion structures. J. Am. Chem. Soc. 2004, 126, 6485 .

[32] M. Rožman, B. Bertoša, L. Klasinc, D. Srzić. Gas phase H/D exchange of sodiated amino acids: why do we see zwitterions? J. Am. Soc. Mass Spectrom. 2006, 17, 29.

[33] M. Rožman. Gas phase structure of sodiated amino acids probed by H/D exchange reactions. Croat. Chem. Acta 2005, 78, 185.

[34] K. A. Newton, S. A. McLuckey. Gas-phase peptide/protein cationising agent switching via ion/ion reactions. J. Am. Chem. Soc. 2003, $125,12404$. 